International Journal of Engineering \& Technology, $7(4.30)(2018) 31-35$
International Journal of Engineering \& Technology
SPC
Website: www.sciencepubco.com/index.php/IJET
Research paper

\title{
Design of Mathematics Student Worksheet based on Realistic Mathematics Education Approach to Improving the Mathematical Communication Ability Students of Class VII Junior High School in Indonesia
}

\author{
Ruri Handayani ${ }^{*}$, Suparman ${ }^{2}$ \\ 1,2 Master of Mathematics Education Ahmad Dahlan University, Indonesia \\ *Corresponding author E-mail: rurihandayani2194@gmail.com1, suparman@pmat.uad.ac.id2
}

\begin{abstract}
Mathematics communication is a way of sharing ideas and clarifying comprehension. The Realistic Mathematics Education (RME) approach can improve mathematical communication skills. The student worksheet is used because it is shorter, more comfortable and summarizes the material along with the questions to be able to assist students in the ability of mathematics communication. This study aims to develop teaching materials in the form of student worksheets based on Realistic Mathematics Education Approach to improve students' mathematical communication skills. This research is development research with ADDIE development model, that is analysis, design, develop, evaluation implementation. The subject of this research is the students of the first grade of VII. Instruments used in the form of validation sheet, mathematics communication ability test, and interview guidance manual. The validation sheet is addressed to material experts and media experts. The test to determine students 'mathematical communication skills is done before and after the use of student worksheet so that it is known whether there is an increase in students' mathematical communication ability. Interview guides are conducted with teachers and students to find out the curricula and character of students in the school. Data analysis techniques in this study using data reduction, presentation, and conclusion. The resulting student worksheet design based on the RME approach that matches the characteristics, curriculum, and student tasks. This research can be developed to the stage of development, implementation, and evaluation.
\end{abstract}

Keywords: Mathematics Communication; RME; Worksheet.

\section{Introduction}

Mathematics communication is a way of sharing ideas and clarifying understanding [1] through the communication of ideas into objects of reflection, improvement, discussion, and change. When students are challenged to communicate their thoughts to others both orally and in writing, they learn to be clear, convincing and appropriate in the use of the language of mathematics. Kaya and Aydin stated that research is being done for experienced teachers, so it is essential to know their views and experiences about their mathematics communication to help improve students 'mathematical thinking and students' mathematical understanding [2]. Discussing the same topic will take a long time, and will lose highability students, while if going to the next level then the lowability students will have difficulty [3]. This is a constraint on how to reach students with low ability and challenge high-ability students. The type of writing can take place in the mathematics classroom, one of which is the theoretical exhibition, it is related to the way the procedure performs and explains the reason of the mathematical results that the students are working on can happen [4]. Floriano and Bernardo say this is where we have the perspective of teaching it in high school years, where students begin to be directed to a group of high-level courses according to a mathematics curriculum that varies according to the subjects in science humanities, art or technology that are followed [5]. The National
Council of Teachers of Mathematics (NCTM) declares that learning programs in kindergarten through high school should give students the opportunity to: Organize and consolidate mathematical thoughts and ideas by communicating them; Communicating their mathematical thinking logically and clearly to his friends, his teacher, and others; Analyze and evaluate other people's mathematical thoughts; and Using mathematics language to express their ideas appropriately [6]. The ability of mathematics communication is one of the topic content tested in the Program for International Students Assessment (PISA). Since participating in PISA in 2000, science education in Indonesia has experienced remarkable transformations to create a foundation for prosperity and sustainable development. Between 2012 and 2015 alone, science performance among 15-year-olds is up 21 points. The proportion size of 15year-olds in countries eligible for PISA assessment are those enrolled in schools in grades 7 or above that have increased by $15 \%$ points in Indonesia since 2006. Looking at states in the region, the level of coverage of Indonesia (68\% of students) is higher than Vietnam (49\%) and is now just below that of Thailand (72\%) [7]. But the ability of mathematics communication is still relatively low, and this can be seen from several studies, namely: Very less field writing from math teachers [8]. Teachers also do not attach importance to the consideration of the relationship between mathematics communication and pedagogy [9]. The results of this study indicate that in geometric proof, the subject explains what it is understood, presents ideas in the form of images and symbols, 
and explains the content/meaning of representation accurately and clearly, but the subject can not pass the argument systematically and logically. Whereas in algebraic evidence, the topic describes the understood, describes the method used, and represents the symbolic representation of the contents/meaning accurately, systematically, logically, but the argument presented is not clear because it is insufficient and complete. The learning method used is the traditional learning method, that is, memorizing mathematical formulas unrelated to real life or student experience this can not improve students' mathematical literacy [10]. A student who has a point of view which is unaware of the relationship of mathematics to real life will assume math is meaningless, and this will affect student academic outcomes in mathematics [11].

Similar results were also found in junior high school Negeri 1 Jetis, Yogyakarta. Efforts to improve students' mathematical communication skills, especially how to express ideas orally and writers will use the expected approach to help overcome the problems that occur by using the approach of Realistic Mathematics Education (RME).

RME is a theory of learning to teach mathematics that began as a movement in the late $60 \mathrm{~s}$ in the Netherlands in an effort to reconsider mathematical education, where up to that time, mechanistic approaches have been dominant. It started in 1968 with the Wiskobas Project, the Dutch abbreviation for mathematics in primary school [12]. RME is the source or starting point for the development of mathematical concepts in real life [13]. RME has been studied by various authors, students' responses to learning by RME students provide a positive response that they feel happy with their learning implementation [14]. RME is one of the most appropriate approaches to teaching mathematics according to the curriculum which in this case focuses on teaching high-level thinking, student skills, including helping build their own knowledge, problem-solving, critical thinking, creative thinking and mathematical communication [15]. Found in this study is the difference in student achievement of learning by using RME with conventional [16]. The survey results found that students taught based on models of addition and subtraction using RME-based ICT had a significant overall improvement in mathematics compared with students taught using traditional teaching [17]. Students in Vietnam are believed to learn mathematical ideas through contextual problem-solving. Therefore, it is expected that teachers in Vietnam can teach math using the RME approach to help students recognize the relationship between abstract mathematics and real life this is seen from research [18]. D Lange $J$ points out that the mathematics learning with the RME approach includes the following aspects: starting the lesson by raising the "rill" problem for students according to their experience and level of knowledge, so that students are immediately involved in meaningful learning; the assigned problem should be directed in accordance with the objectives to be achieved in the learning; students develop or create informal symbolic models of the problem/problem posed; teaching takes place interactively: the student explains and gives the reason the person he or she is giving, understands the friend's answer, agrees with the friend's answer, expresses disapproval, seeks other alternative solutions; and reflect on each step taken or on the outcome of the lesson [19].

To support the implementation of RME in need of teaching materials, learning media and assessment of learning outcomes. The student worksheet is one of the teaching materials. However, based on observations and interview guidance with one of the VII junior high school teachers of Junior High School 1 Jetis, Yogyakarta, it is known that the student worksheets used in mathematics lessons still do not improve students' mathematical communication skills. So the need for the development of a supportive student worksheet. The developed student worksheet is expected to train students' mathematical communication skills to apply and deepen the mathematical concepts of students are still less able to communicate their opinions about mathematics to the real world and not yet used to express ideas in the form of oral and written form. They also find problems when determining the stages to find solutions to problems when looking for answers and what kind of patterns they will use. Based on this, it takes an effort to improve the students' mathematics communication skills.

Improved learning quality begins with the enhancement of the quality of instructional design, and to create an exciting learning tool, in its creation must be by the methods and models that match the needs of the students for learning to be meaningful [20]. Therefore, teachers need to find solutions so that students can understand math easily. One solution that can be considered is developing teaching materials in the form of student worksheets [21]. This article proposes the design of a mathematics course based mathematics student approach to improve the ability of mathematical communication.

\section{Method}

This type of research is development research. The research model used in this research is ADDIE. The ADDIE model is one of the instructional designed [22]. This model phase includes analysis, design, development, implementation, and evaluation. This involves educational goals and determining what needs to be taught to complete educational purposes. First, the design phase of educators creates a broad range of explanations that explain how to deliver instructions to fulfill the objectives undertaken during the analysis process. In the next stage of development, each instructional component is presented in as much practical detail as possible to complete in the design phase. At the implementation stage, educators provide instructions with or without first implementing smaller projects. Finally, the evaluation phase of the educator gets feedback on the program and makes adjustments to the teaching program. The subject of this study is the grade VII junior high school students 1 Jetis, Yogyakarta. During the process of each phase, it is important to remember that movements from stage one to the next are not exclusively linear [23 ]. Samples were taken from class VII B by involving teachers, students, material experts and media experts. The object of this research Data collection methods undertaken in this study was taken by providing tests and interview guidelines.

Instruments used in the form of validation sheet, mathematics communication ability test, and the interview guide. The validation sheet is addressed to material experts and media experts. The test to determine students 'mathematical communication skills is done before and after the use of student worksheet so that it is known whether there is an increase in students' mathematical communication ability. Interview guides are conducted with teachers and students to find out the curricula and character of students in the school.

Data analysis technique in this research is data reduction [24]. Data obtained from observations and interview guidelines conducted in schools are then summarized and concluded. From the analysis results obtained a clear picture of the things that are needed in the development of student worksheets to be done. Namely data reduction, presentation, and conclusions.

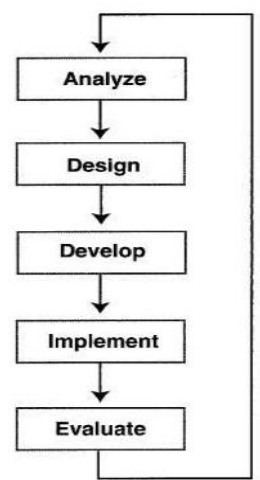

Fig. 1: Development Process [25] 


\section{Results and discussion}

\subsection{Analysis}

The ADDIE model analysis phase identifies the performance gap, the difference between the standard set in the standard operating procedure (SOP) and some teacher performance. Performance gaps are usually handled by learning products, namely: a collection of training and assessment materials. In the analysis phase in doing some stages are

Stage 1: Curriculum analysis, to know the competence or content that will be developed in the student worksheet. The results obtained are junior high school Negeri 1 Jetis, Yogyakarta using the 2013 curriculum which refers to Permendikbud No. 68 of 2013 on the essential competition and Structure of the junior secondary school curriculum.

Stage 2: Validating performance gaps, knowing the ability of student communication skill hence conducted test of student communication ability and interview guidance of teacher and student. It is found that the test scores of students' mathematical communication ability is still low or low. While the result of interview guidebook of student still difficulties in delivering opinion material in oral and written form.

Stage 3: Determining objectives, activities were determining what goals will be implemented in the future. In this study, the authors develop teaching materials namely Student Worksheet.

Stage 4: Analysis material, the activities were identifying, detailing and compiling material to be written in the student worksheet. And what is obtained in this analysis is the material of class VII even semester [25].

\subsection{Design}

Stage Design follows the analysis, which is done at the design stage are:

1.Adjust the proposed learning product into a larger curriculum. The proposed learning product refers to the 2013 curriculum.

2.Describe the proposed learning product, at this stage divided into several parts:

3. a. The opening section

4.In this section there are several parts, namely cover (Figure 2); introduction (Figure 3); table of contents (Figure 4); Indicator (Figure 5); Concept (Figure 6), (6.a), (6.b), (6.c), (6.d)

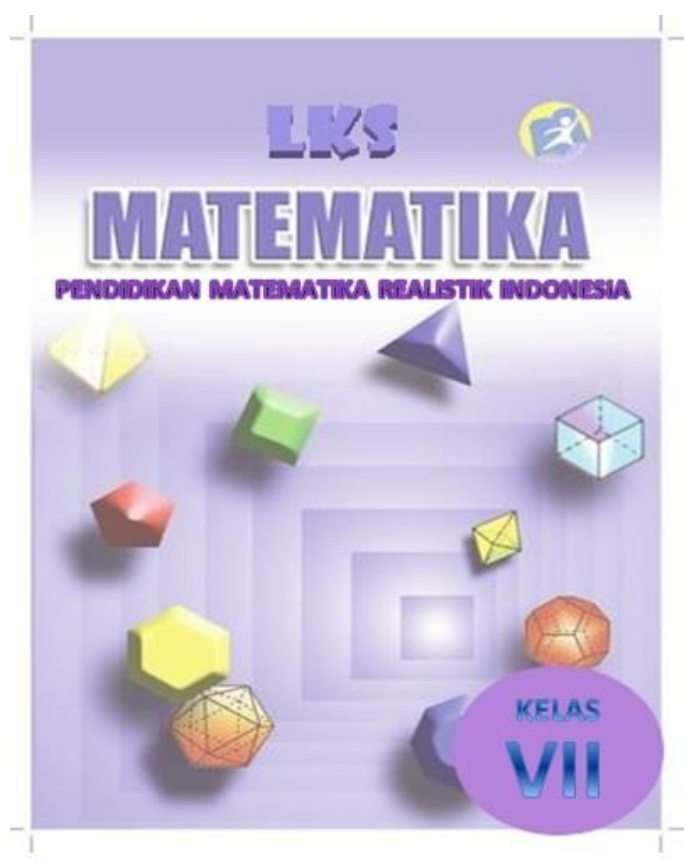

Fig. 2: Cover

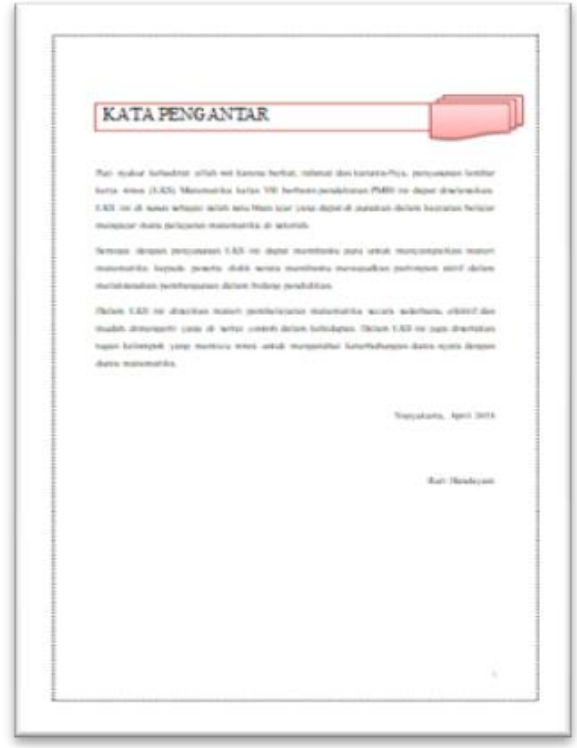

Fig. 3: Introduction

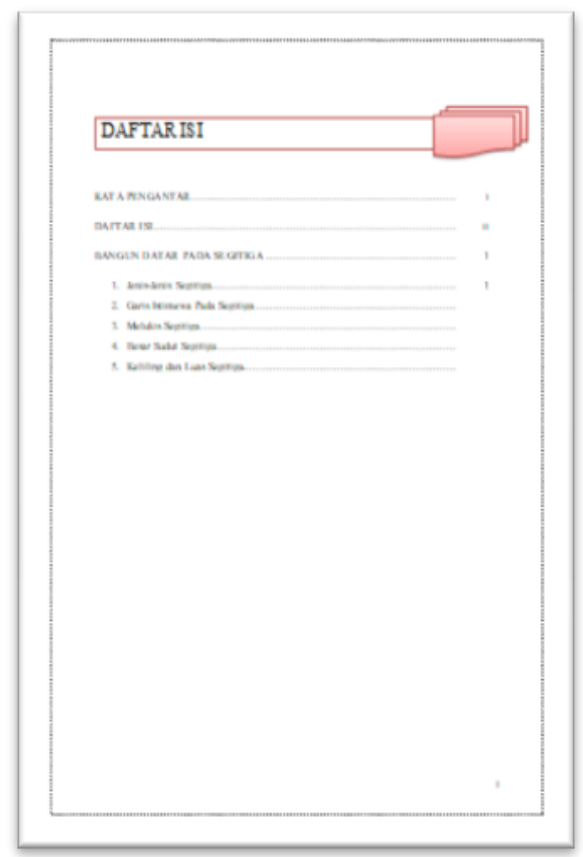

Fig. 4: Table of Contents

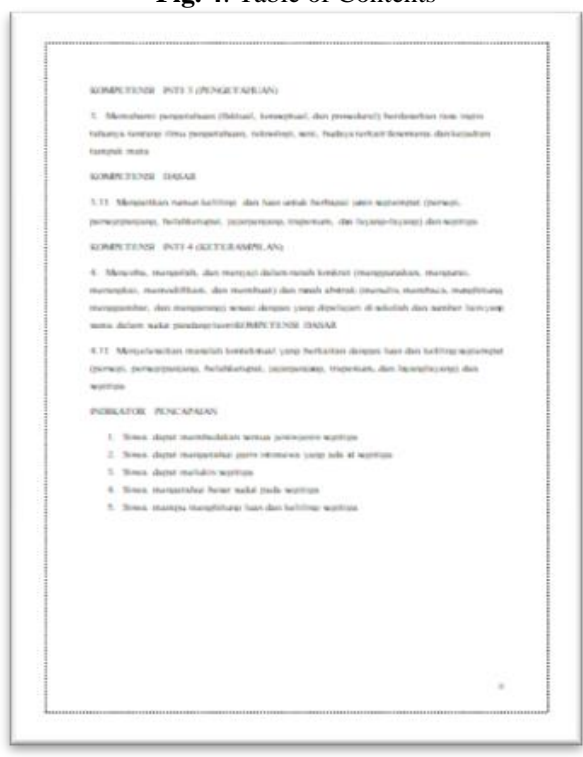

Fig. 5: Indicator 
b) The content section, consisting of chapter titles, material summaries, exercise questions and evaluation. Concepts (Figure 6)

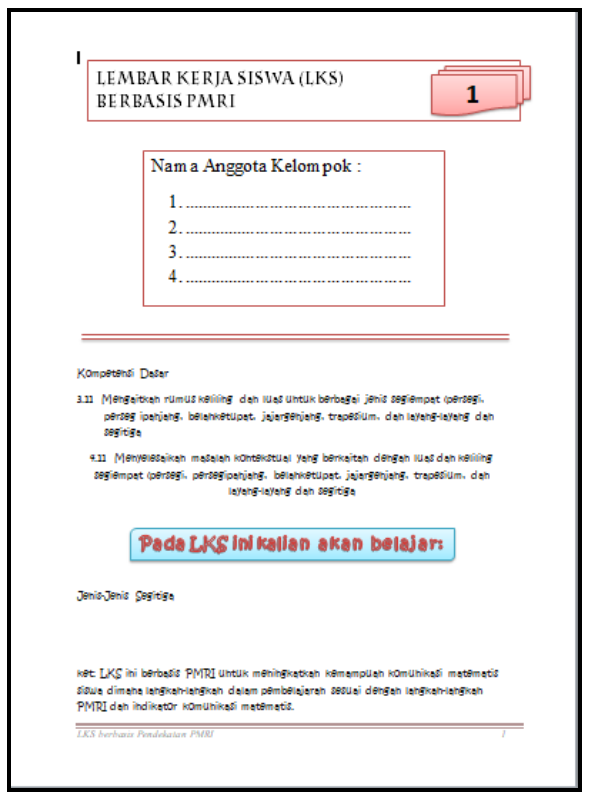

Fig. 6: Concepts

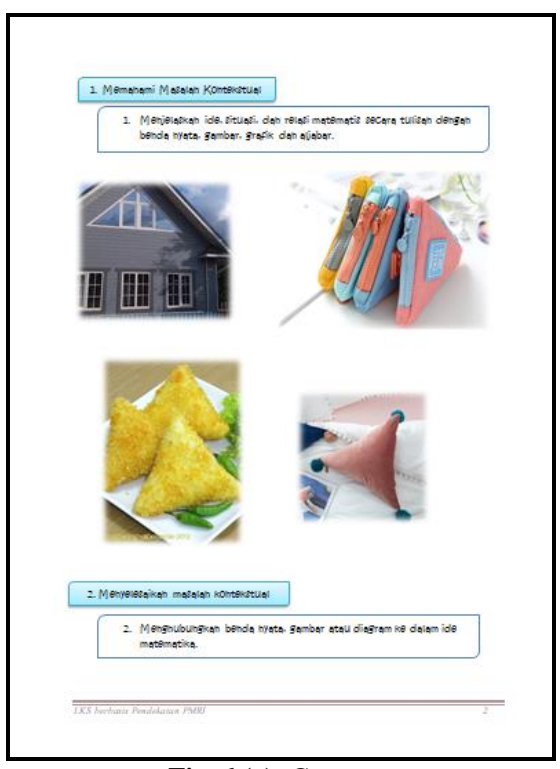

Fig. 6 (a): Concepts

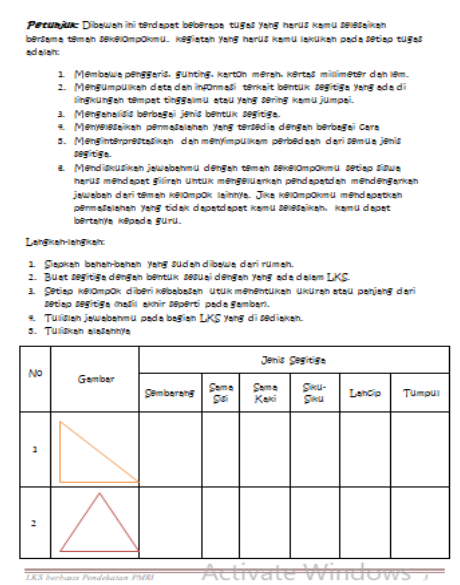

Fig. 6 (b): Concepts

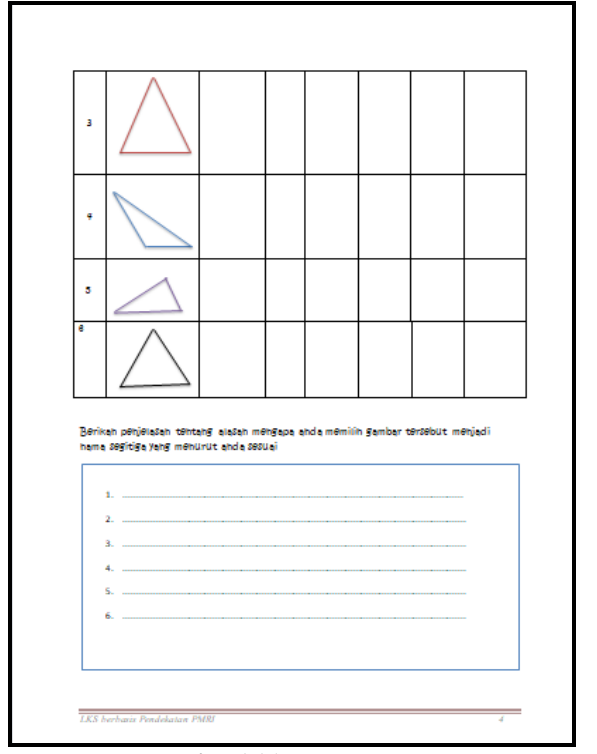

Fig. 6 (c): Concepts

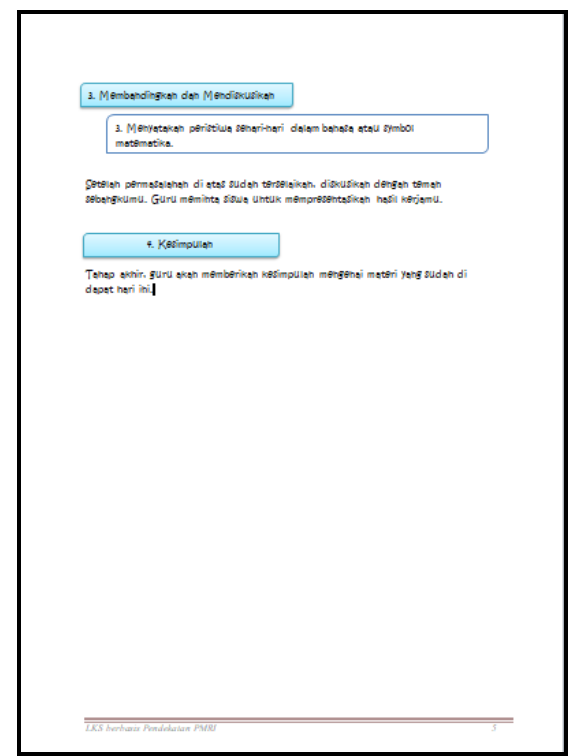

Fig. 6 (d): Concepts

c) The closing section, consisting of a glossary, bibliography, and answer key.

\section{Conclusions}

This research resulted in the design of student worksheets based on the RME approach that suits the characteristics, curriculum, and student tasks. Student worksheets are designed to improve students' mathematical communication skills. Designing student worksheets are part of the ADDIE development procedure. The student worksheet component consists of three parts: a) The opening section, comprising of cover, table of contents, introductory words, and instructions for use; b) The content section, containing of chapter titles, material summaries, exercise questions and evaluation; and c) The closing section, consisting of a glossary, bibliography, and answer key. The content section contains the RME principles: guided reinvention, didactical phenomenology (selfdeveloped phenomenon), self-developed models (selfdevelopment models).

Indicators of mathematics communication capabilities are also included in the RME stages that are present on this part of the student worksheet. Research can be further developed at the stage of development and dissemination. 


\section{Suggestion}

The design worksheet student Realistic Mathematics Education is designed to improve the communication mathematics abilities of seven-grade high school students. This research can be developed in the development stage and to the field testing phase to determine the practicality and effectiveness of the student worksheet.

\section{References}

[1] NCTM, "Principles and Standards for School Mathematics". Association Drive Reston. (2000).

[2] Kaya. D \& Aydın. H, "Elementary Mathematics Teachers Perceptions and Lived Experiences on Mathematical Communication", Eurasia Journal of Mathematics Science \& Technology Education, Vol.12, No.6, (2016), pp:1619-1629.

[3] Schultz C, "Mathematical Communication and Achievement Through", Journal Writing Summative Projects, for MA Degree 27.

[4] Santos L \& Semana S, "Developing Mathematics Written Communication Through Expository Writing Supported by Assessment Strategies", Education Stud Math, Vol. 88, (2015), pp. 65-87.

[5] Floriano \& Bernardo I, "Open-ended Tasks in The Promotion of Classroom Communication in Mathematics", International Electronic Journal of Elementary Education, Vol.4, No.2, (2012), pp. 287-300

[6] NCTM, "Curriculum and Evaluation Standards for School Mathematics,", Reston VA Authur, (1989), available online: http://educare e-fkipunla.net

[7] PISA (2015), Result in Focus https://www.oecd.org/pisa/pisa-2015results-infocus pdf accessed on 27 March 2018 at 21.00 WIB.

[8] Kabael T \& Baran A A, "Prospective Middle School Mathematics Teachers Mathematical Communication Mathematical and Pedagogical Knowledge”, Kastamonu Eğitim Dergisi, Vol. 25, No.5, (2017), pp. 1909-1924.

[9] Pantaleon KV, Juniati D, Lukito A \& Mandur K, "The Written Mathematical Communication Profile of Prospective Math Teacher in Mathematical Proving", Journal of physic, (2018), pp. 17426596.

[10] Sumirattana S, Makanong A, \& Thipkong S, "Using Realistic Mathematics Education and The DAPIC Problem-Solving Process to Enhance Secondary School Student Mathematics Literacy", $\mathrm{Ka}$ setsart, Journal of Social Sciences, Vol.38, (2017), pp.307-315.

[11] Mumcu HY, "Examining Mathematics Department Students Views on The Use of Mathematics in Daily Life", International Online Journal of Education and Teaching (IOJET), Vol.5, No.1, (2018), pp.61-80.

[12] Traffers A, "Three Dimensions A Model of Goal and Theory Description in Mathematics Education Dordrecht Reidel, (1987).

[13] Freudental H, Revisiting Mathematics education, China Lectures Dordrecht Kluwer, (1991).

[14] Warsito, Darhim \& Herman T, "Improving Students Mathematical Representation Ability Through RME-based Progressive Mathematization", Journal Phys Conference Series, No.948 01203, (2018).

[15] Palupi ELW \& Khabibah S, "Developing workshop module of realistic mathematics education Follow-up workshop IOP", Conf. Ser Mater Sci Eng 296 012006, (2018).

[16] Laurens T, Batlolona FA, Batlolona JR \& Leasa M, "How Does Realistic Mathematics Education (RME) Improve Students Mathematics Cognitive Achievement", EURASIA Journal of Mathematics Science and Technology Education, Vol.14, No.2, (2018), pp. 569578.

[17] Zaranis N, "Does The Use of Information and Communication Technology through the use of Realistic Mathematics Education help kindergarten students to enhance their effectiveness in addition and subtraction?", Preschool and Primary Education, Vol. 5, No.1 (2017), pp. 46-62.

[18] Loc NP \& Hao MH, "Teaching Mathematics Based On Mathematization Of Theory of Realistic Mathematics Education: A Study of the Linear Function $\mathrm{Y}=\mathrm{Ax}+\mathrm{B}$ ", The International Journal Of Engineering And Science (IJES), Vol.5, No.6, (2016), pp. 20-23.

[19] Lange DJ, "Mathematics Insight and meaning Disertasi Doktor Frudenthal Institute", (1987).

[20] Purba GID, Surya E, Manullang M \& Asmin, "The Effect of Students Worksheet in the Model of Discovery Learning Against the Students Ability of Reasoning and Mathematical Communication in the Faculty of Mathematics and Natural Science of State University of Medan", International Journal of Sciences Basic and Applied Research (IJSBAR), Vol.37, No.3, (2018), pp. 70-82.

[21] Zulyadaini, "Development of Student Worksheets Based Realistic Mathematics Education (RME) Batanghari" International Journal of Engineering Research and Development, Vol.13, No.1, (2017), pp, 30-38.

[22] Piskurich GM, "What is this instructional design stuff anyway?" in Rapid Instructional Design Learning USA, (2015).

[23] Cheung L, "Using the ADDIE Model of Instructional Design to Teach Chest Radiograph Interpretation" Journal of Biomedical Education Article, (2016), ID 9502572, available online http://dx.doi.org/10.1155/2016/9502572

[24] Miles MB, Huberman AM \& Saldana J, "Qualitative Data Analisis, A Methods Sourcebook” Edition 3 USA Sage Publications. Translated by Tjetjep Rohendi Rohisi Jakarta Universitas Indonesia, (2014).

[25] Welty G, "The Design Phase of the ADDIE Model", Journal of GXP Compliance, Vol.11, No.4, (2007), pp. 40-48.

[26] Hsu TC, Hsieh JL, Turton MA \& Cheng SF, "Using the ADDIE Model to Develop Online Continuing Education Courses on Caring for Nurses in Taiwan", Journal of Continuing Education in Nursing, Vol.45, No.3, (2014), pp. 124-131 